\title{
Perubahan Epidemiologi Demam Berdarah Dengue Di Indonesia
}

\author{
Mulya Rahma Karyanti, Sri Rezeki Hadinegoro \\ Departemen Ilmu Kesehatan Anak Rumah Sakit Dr. Cipto Mangunkusumo FKUI Jakarta
}

\begin{abstract}
Dengue berdarah dengue yang ditularkan melalui vektor nyamuk Aedes aegypty masih merupakan masalah kesehatan penting di dunia. Di Indonesia, demam berdarah dengue mulai dikenal pertama kali pada tahun 1968 di DKI Jakarta dan Surabaya, dan terus menyebar ke seluruh tiga puluh tiga propinsi di Indonesia. Pola epidemiologi infeksi dengue mengalami perubahan dari tahun ke tahun, jumlah kasus memuncak setiap siklus 10 tahunan. Dari tahun 1968-2008 angka kesakitan demam berdarah dengue terus meningkat. Pada tahun 2008 didapatkanangka kesakitan 58,85/ 100.000 penduduk. Angka kematian menurun dengan stabil dari $41 \%$ pada tahun 1968 menjadi kurang dari $2 \%$ sejak tahun 2000, dan pada tahun 2008 angka kematian menurun menjadi 0,86\%.Semua serotipe virus dengue ditemukan di Indonesia, namun serotipe virus den-3 masih dominan menyebabkan kasus dengue yang berat dan fatal. Surveilans epidemiologi, dukungan edukasi masyarakat dan program pengendalian vektor diperlukan untuk mencegah transmisi. Pengembangan vaksin dengue merupakan salah satu upaya mencegah penyakit dengue. (Sari Pediatri 2009;10(6):424-32).
\end{abstract}

Kata kunci: demam berdarah dengue, epidemiologi

$\mathrm{D}$ emam dengue (DD)/ demam berdarah dengue (DBD) secara epidemiologi di dunia berubah secara cepat. Infeksi dengue merupakan penyakit menular melalui nyamuk (mosquito-borne) yang paling sering terjadi pada manusia dalam beberapa tahun terakhir, sehingga masih merupakan masalah kesehatan dunia. World Health Organization mengestimasi bahwa 2,5 miliard manusia tinggal di

\footnotetext{
Alamat Korespondensi:

Dr. Mulya Rahma Karyanti., SpA. Divisi Infeksi dan Penyakit Tropis Departemen Ilmu Kesehatan Anak Rumah Sakit Dr. Cipto Mangunkusumo FKUI Jakarta 10430. Tel. (021) 391 4126. Fax. (021) 3907743
}

daerah virus dengue bersirkulasi. ${ }^{1,2}$ Penyebaran secara geografi dari kedua vektor nyamuk dan virus dengue menyebabkan munculnya epidemi demam dengue dan demam berdarah dengue dalam dua puluh lima tahun terakhir, sehingga berkembang hiperendemisitas di perkotaan di negara tropis. Pada tahun 2007 di Asia Tenggara, dilaporkan peningkatan kasus dengue sekitar $18 \%$ dan peningkatan kasus dengue yang meninggal sekitar $15 \%$ dibanding tahun $2006 .{ }^{3}$

Di Indonesia demam berdarah dengue masih merupakan masalah kesehatan masyarakat yang penting. Infeksi dengue terjadi secara endemis di Indonesia selama dua abad terakhir dari gejala yang ringan dan selflimiting disease. Dalam beberapa tahun 
terakhir, penyakit ini memiliki manifestasi klinis yang semakin berat sebagai demam berdarah dengue dan frekuensi kejadian luar biasa meningkat. Indonesia merupakan negara dengan jumlah populasi yang padat mencapai 245 juta penduduk. Hampir $60 \%$ penduduk tinggal di pulau Jawa, daerah kejadian luar biasa infeksi dengue terjadi. ${ }^{4}$ Walaupun demikian, penyakit dengue banyak dilaporkan di kota besar dan pedesaan di Indonesia dan telah menyebar sampai di desa-desa terpencil oleh karena perpindahan dan kepadatan penduduk yang tinggi. ${ }^{5}$

\section{Angka kesakitan dan angka kematian}

Pada tahun pertama diketahui infeksi dengue di Indonesia, dilaporkan 58 kasus di DKI Jakarta dan Surabaya (termasuk 24 kasus yang meninggal). ${ }^{5}$ Pada tahun 1970, 24 kasus dengue diidentifikasi diantara 48 kasus anak tersangka dengue di Yogyakarta. ${ }^{6}$ Selanjutnya, 8 kasus diklasifikasikan DBD dan 2 kasus berkembang menjadi SSD.

Pada tahun 1997, 2004 dan 2005 Depkes melaporkan angka kematian dengue berurutan adalah 15,2 per 100.000 orang, 30 per 100.000 orang dan 13,7 per 100.000 orang. $^{2}$ (tidak dipublikasi, sumber data dirjen P2MPL Depkes RI). Pada tahun terakhir, penyakit dengue mengakibatkan lebih dari 400 kematian setiap tahun di Indonesia dan tahun 1998 angka ini meningkat mencapai 1414 . Jika terapi cairan adekuat, maka angka kematian di negara Asia bisa menurun berkisar antara $0,5 \%$ dan 3,5\%. ${ }^{7}$

Sejak tahun 1968-2008 kasus demam berdarah dengue meningkat terus. Pada gambar 1 . terdapat jumlah kasus demam berdarah dengue yang memuncak setiap 10 tahun sekali, yaitu pada tahun 1988, 1998 dan 2008. Pada tahun 2008 data dari Departemen Kesehatan menunjukkan jumlah kasus demam berdarah dengue mencapai 133,402 kasus dengan angka kesakitan (incidence rate) 58,85/100.000 penduduk.

Di Indonesia, angka kematian (case fatality rate) menurun dengan stabil dari 41\% pada tahun 1968 menjadi kurang dari $2 \%$ sejak tahun 2000, menurun menjadi $1,21 \%$ pada tahun $2004,{ }^{1}$ dan pada tahun 2008 angka kematian sudah menurun menjadi 0,86\%. Pada tahun 2008 angka kesakitan tertinggi terjadi pada propinsi DKI Jakarta (303,5), Kalimantan Timur $(174,6)$ dan Bali $(170,1)$, sedangkan angka kematian tertinggi terjadi di propinsi Maluku (3,66\%), Kalimantan Barat (3,53\%), dan Nusa Tenggara Timur $(2,87 \%)$.

Sejak tahun 1968-1995 di Indonesia kasus DBD terutama menyerang kelompok umur 5-14 tahun, tetapi setelah tahun 1984 insidens kelompok umur lebih dari 15 tahun meningkat dari tahun ke tahun. Pada tahun 2007 di provinsi DKI Jakarta, persentase kasus DBD terbanyak merupakan kelompok umur 5-14 tahun (36\%), diikuti kelompok umur lebih dari 5 tahun (31\%), kelompok 15-44 tahun (22\%) dan lebih dari 45 tahun (11\%). Data dari tahun 2006 menunjukkan proporsi jenis kelamin lelaki lebih banyak dibanding perempuan pada semua kelompok umur.

\section{Gambaran epidemiologi}

Kasus infeksi dengue pertama di Indonesia dilaporkan pada tahun 1968 di kota DKI Jakarta dan Surabaya., ${ }^{5,9}$ Kemudian dilanjutkan dengan laporan dari Bandung dan Yogyakarta. ${ }^{6,10}$ Sejak saat itu tersangka kasus dengue dilaporkan oleh Departemen Kesehatan. Awalnya, angka kesakitan dilaporkan hanya di pulau Jawa dengan jumlah kasus yang terbatas. ${ }^{5,8,9}$ Pada awal tahun 1980-an, laju angka kesakitan meningkat dari 10000 sampai 30000 per tahun, dan sejak sepuluh tahun terakhir laju angka kesakitan telah meningkat dari 30000-60000 kasus per tahun.

Meningkatnya kasus dengue secara bermakna dilaporkan terjadi pada tahun 1973 dan 1988, dan pada tahun 1998 dan 2004 dilaporkan berturut-turut 73133 dan 78680 kasus. Kini, infeksi dengue telah menyebar merata di antara 33 propinsi di Indonesia, dengan latar belakang interepidemis antara 1000025000 kasus setiap tahun.

Kejadian luar biasa dengue pertama dilaporkan terjadi tahun 1973 (Gambar 1). Dari 10189 kasus yang dilaporkan, 6225 kasus didiagnosis di Semarang, tidak didapatkan data mengenai derajat beratnya penyakit. ${ }^{5}$ Pada tahun berikutnya dilaporkan kejadian luar biasa di luar pulau Jawa yaitu di Manado, Sulawesi Utara. ${ }^{11}$ Suatu epidemik demam berdarah dengue dengan derajat berat dan viremia tinggi dilaporkan di Bantul, Jawa Tengah pada akhir tahun 1976 dan awal $1977 .{ }^{12,13}$ Pada semua kasus sindrom syok dengue (SSD), tidak ditemukan hubungan antara serotipe dengue dan derajat beratnya penyakit, walaupun demikian tiga 


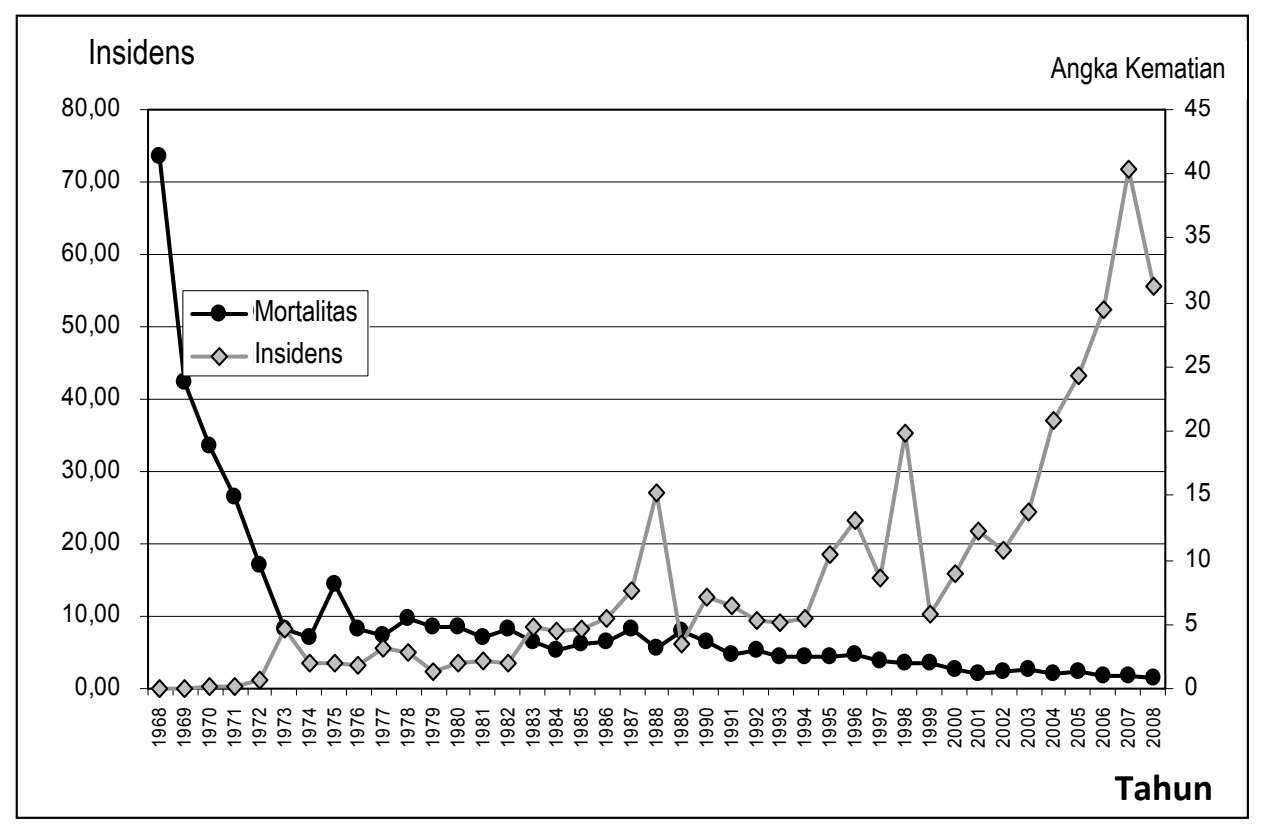

Gambar 1. Insidens dan angka kematian DBD per tahun di Indonesia tahun 1968-2008

kasus fatal berhubungan dengan virus den-3. Satu tahun kemudian suatu kejadian luar biasa den-3 terjadi di Sleman, $40 \mathrm{~km}$ utara Bantul, yang memiliki gejala ringan. ${ }^{14}$ Distribusi umur hampir mirip dengan wabah di Bantul, namun penyakit tidak seberat yang dilaporkan pada wabah di Bantul (kasus SSD di Bantul 37\% dan Sleman 13\%).

Dari tahun 1975 sampai 1983, 1451 kasus DBD dengan konfirmasi serologi dengan uji inhibisi hemaglutinasi di Jakarta diikuti selama dirawat di rumah sakit. ${ }^{15}$ Dari semua kasus tersebut, 142 diantaranya dikonfirmasi secara virologi. Kasus fatal ditemukan pada 34 infeksi dengue yang dikonfirmasi secara virologi dan pada kasus DBD dengan syok (77\% dari kasus yang fatal). Virus den-3 merupakan virus yang paling sering berhubungan dengan infeksi yang berat dan fatal.

Kejadian luar biasa selama lima bulan muncul di bulan September 1993 sampai Februari 1994 di kota Jayapura, Papua, walaupun kasus pertama DBD dilaporkan terjadi tahun 1979, dan sempat menghilang beberapa tahun. ${ }^{16}$ Sejumlah 217 kasus DBD dilaporkan dari Jayapura dan 72 tersangka kasus DBD dilaporkan pada saat investigasi kejadian luar biasa. ${ }^{16}$ Sebagian besar kasus $(68,7 \%)$ tidak memiliki peningkatan kadar IgM yang bermakna pada saat pasien masuk rumah sakit, $11,4 \%$ mengalami infeksi dengue primer, $17,1 \%$ memiliki infeksi sekunder dan sisanya tidak dapat ditentukan (indeterminate). Sembilan kasus pemeriksaan kultur positif dari 63 spesimen darah (whole-blood) dan 68 sampel serum yang diinokulasi dari nyamuk.

Suatu penelitian kohort prospektif yang dimulai pada tahun 1995 menunjukkan bahwa insidens dari satu/lebih infeksi dengue 29,2\% pada kelompok umur 4-9 tahun di Yogyakarta pada tahun pertama penelitian. ${ }^{17}$ Sekitar 56,2\% memiliki antibodi terhadap satu atau lebih tipe virus pada awal penelitian, dan $34,3 \%$ dari seluruh kasus terbukti secara serologi telah terpapar dengan satu serotipe. Pada kasus anak yang terbukti secara serologi belum pernah terpapar infeksi dengue sebelumnya, 26,8\% (216 dari 805) mengalami serokonversi dan enam dari 1837 kasus yang dirawat memiliki infeksi sekunder/tersier.

Selama periode November 1997 sampai 1998, kejadian luar biasa DBD terjadi kembali di seluruh wilayah Indonesia. ${ }^{18}$ Sebelas propinsi yang terlibat dan semua kejadian luar biasa terjadi di daerah perkotaan. Kejadian luar biasa dimulai bulan November 1997 di Jambi, Sumatra Selatan dan Lampung. Kemudian kejadian luar biasa menyebar ke seluruh propinsi di Sulawesi, Nusa Tenggara Barat, dan Timor Timur, melanjut ke Ambon, Maluku, dan akhirnya mencapai Jakarta pada bulan Maret 1998. Rerata attack rate 1,2 
per 1000 populasi, tertinggi terjadi di Palembang, Sumatra Selatan (1,6 per 1000 populasi).

Kecenderungan terjadi kejadian luar biasa di Palembang pada tahun 1998 menunjukkan peningkatan kasus dengue mencapai tiga kali lipat antara bulan Januari sampai April. ${ }^{19}$ Tampak perubahan transmisi epidemik yaitu dari kelompok umur 5 tahun ke kelompok umur remaja dan dewasa muda yang terinfeksi dengue.

Suatu penelitian kohort prospektif dilakukan pada 2536 dewasa pekerja pabrik tekstil di Bandung mulai tahun 2000 sampai $2002 .{ }^{20}$ Insidens penyakit dengue simtomatik terjadi pada 18 kasus per 1000 orang-tahun dan laju infeksi asimtomatik/ringan terjadi pada 56 kasus per 1000 orang-tahun.

Pada bulan April 2001, kejadian luar biasa kedua terjadi di Papua. ${ }^{21}$ Di Merauke, suatu penelitian kasus kontrol retrospektif dilakukan pada 15 kasus DBD akut, 37 kasus konvalesen dan 32 kasus kontrol. Antibodi IgM virus dengue ditemukan pada $27 \%$ kasus klinis akut, 30\% pada kasus konvalesen dan hanya 3\% pada kasus kontrol. Dengue virus den-3 merupakan satu-satunya serotipe virus dengue yang terdeteksi dengan RT-PCR, semua dari sampel kasus akut. Dari evaluasi catatan medik, 172 tersangka kasus teridentifikasi. Angka kematian berkisar 1,2 \% dari semua kasus tersangka dengue.

Penelitian mengenai perjalanan penyakit infeksi dengue dilakukan di Jawa Barat pada 785 orang sukarelawan dengan menggunakan metoda penelitian kluster pada periode Oktober 2001-2003. Semua subjek merupakan keluarga atau tetangga dari 53 kasus indeks, yang sebelumnya dirawat di rumah sakit. ${ }^{22}$ Pada saat penerimaan sampel kasus, ditemukan 11 subjek mengalami viremia (3 kasus den-1, 8 kasus den-2). Isolasi virus dapat dilakukan pada lima kasus tersebut. Tujuh belas kasus dengan infeksi baru $(2,2 \%)$ teridentifikasi pada saat post-enrollment (setelah penerimaan pasien). Sepuluh didapatkan hasil RT-PCR positif( 1 kasus den-1, 7 den-2, 1 den-3 dan 1 den-4). Pada kelima kasus serotipe dikonfirmasi dengan kultur darah. Satu dari sembilan subjek post enrollment yang simtomatik, berkembang menjadi DBD. Pada penelitian Beckett dkk tersebut, disimpulkan insidens infeksi dengue yang terjadi adalah 567 kasus per 1000 orang-tahun yang di tindak lanjuti, sedangkan insidens DBD 33 kasus DBD per 1000 orang-tahun.

Pada tahun 2004, terjadi kejadian luar biasa lagi yang mulai menyebar ke seluruh Indonesia, dengan kota Jakarta yang paling banyak melaporkan kasus. ${ }^{23}$ Berdasarkan laporan WHO, 78690 kasus dan lebih dari 900 kematian dilaporkan di Indonesia pada tahun tersebut. Penelitian kohort dilakukan pada 272 pasien yang dirawat untuk mengkonfirmasi etiologi penyakit di sepuluh rumah sakit, yang berlokasi di Indonesia. ${ }^{4}$ Infeksi dengue ditemukan pada $66,2 \%$ dari semua kasus, 55,6\% dengan demam dengue, 17,2\% dengan demam dengue dengan manifestasi perdarahan, dan 27,2\% dengan DBD. Dari kasus DBD yang dikonfirmasi, 82,5\% terbukti mengalami infeksi sekunder. Isolasi virus dilakukan pada 28 serum akut dari kasus yang secara serologi positif dan teridentifikasi keempat serotipe dengue. Infeksi dengue lebih banyak pada kelompok umur lebih dari 15 tahun.

Pada bulan Maret sampai Desember 2006 dikumpulkan 141 pasien dengue yang terdiri dari 22 anak dan 119 dewasa yang dilakukan pemeriksaan serologi inhibisi hemaglutinasi. Dari sampel tersebut hanya 116 sampel memiliki pasangan sera. Didapatkan infeksi sekunder 66,4\%, 2 (1,7\%) kasus negatif dan 7 kasus $(7,7 \%)$ tidak dapat ditentukan. Pada tahun 2007 didapatkan 97 kasus dengue terdiri dari 47 anak dan 50 dewasa. Kemudian dilakukan pasangan sera dengan interval demam 3-7 hari. Pemeriksaan rapid immunochromatografic assay menunjukkan bahwa 66 sampel memiliki infeksi sekunder, 11 sampel infeksi primer dan 19 sampel negatif. ${ }^{24}$

Data serologi pasien dengan infeksi dengue dari Divisi Infeksi dan Pediatri Tropik, Departemen Ilmu Kesehatan Anak FKUI-RSCM dari tahun 2007 2009 menunjukkan bahwa kasus demam berdarah dengue sebagian besar $(>80 \%)$ disebabkan oleh infeksi sekunder. Sedangkan kasus demam dengue pada tahun 2007-2008 sebagian besar (>83\%) disebabkan oleh infeksi sekunder dan pada tahun 2009 sejumlah $56,25 \%$ kasus demam dengue disebabkan oleh infeksi primer. ${ }^{25}$ (Tabel 1)

\section{Virologi}

Pada tahun 1960-an, diagnosis klinis DBD dibuat berdasarkan ditemukannya demam tanpa penyebab yang jelas disertai perdarahan dengan atau tanpa syok. Diagnosis klinis didukung oleh pemeriksaan inhibisi hemaglutinasi. Pada saat itu tidak ada data isolasi virus. Isolasi virus dengue pertama berlangsung di Jakarta, Medan, dan Semarang pada tahun 1970., ${ }^{6,13,26,27}$ 
Mulya Rahma Karyanti dkk: Epidemiologi DBD Di Indonesia

Tabel 1. Hasil serologi infeksi dengue di Departemen Ilmu kesehatan Anak RSCM-FKUI. ${ }^{25}$

\begin{tabular}{lllll}
\hline & Tahun & 2007 & 2008 & 2009 \\
\hline Demam dengue & Infeksi primer & $2(16.67 \%)$ & $5(14.71 \%)$ & $9(56.25 \%)$ \\
& Infeksi sekunder & $10(83.33 \%)$ & $29(85.29 \%)$ & $7(43.75 \%)$ \\
Demam berdarah dengue & Infeksi primer & $12(14.46 \%)$ & $9(7.38 \%)$ & $7(20 \%)$ \\
& Infeksi sekunder & $71(85.54 \%)$ & $113(92.62 \%)$ & $28(80 \%)$ \\
\hline
\end{tabular}

Data terbatas menunjukkan bahwa den-2 merupakan virus predominan pada saat itu, ${ }^{28}$ dan den-2 diisolasi paling sering pada saat epidemi di Semarang tahun 1973. ${ }^{13}$ Kejadian luar biasa di Manado tahun 1974 menunjukkan bahwa dari 125 kasus teridentifikasi den-1 merupakan virus yang predominan pada kasus syok dan nonsyok. ${ }^{11}$ Surveilans virologi dengan menggunakan teknik inokulasi nyamuk dilakukan pada periode tahun 1975-1979 di delapan kota di Indonesia. ${ }^{15}$ Dari seluruh 297 kasus DBD yang berhasil diisolasi, keempat serotipe virus ditemukan dengan den-3 yang predominan.

Pada awal 1976, den-3 merupakan serotipe yang paling sering berhubungan dengan kasus fatal di Jakarta. ${ }^{29}$ Epidemik DBD yang berhubungan dengan den-3 terus berlangsung pada tahun 1977 di Jawa dan Kalimantan Barat. ${ }^{29}$ Diduga virulensi den-3 mengalami perubahan. Selama epidemi di Bantul pada akhir tahun 1976, isolasi virus berhasil dilakukan dari 69 pasien yang memiliki kenaikan antibodi inhibisi hemaglutinasi lebih atau sama dengan 4 kali lipat antara serum akut dan konvalesen. Sembilan puluh lima kasus berhasil diisolasi dan serotipe yang ditemukan adalah den-3(60\%), den-4(22,2\%), dan den-1(17,8\%). Dari semua pasien infeksi virus dengue yang diklasifikasikan infeksi primer, virus dengue berhasil diisolasi, sedangkan kasus dengan infeksi sekunder hanya berhasil diisolasi 57\% kasus. Viremia yang terjadi mencapai lima kali lipat pada infeksi sekunder dibanding infeksi primer.

Data dari epidemi di Sleman tahun 1978 menunjukkan bahwa den-3 dapat diisolasi delapan kali dari 25 sampel akut (32\%), serotipe lainnya tidak ditemukan. Dari isolasi didapatkan infeksi primer $45 \%$ dan infeksi sekunder 23\%. Viremia secara keseluruhan kasus di Sleman lebih rendah dibanding dengan Bantul (Bantul 67\% titer den-3 10^6MID ${ }_{50}$ per mil, Sleman $37 \%$ titer den-3 $>10^{\wedge} 6 \mathrm{MID}_{50}$ per mil). ${ }^{2}$

Antara tahun 1980 dan 1983 , sejumlah 164 isolasi, menggunakan teknik inokulasi nyamuk, dilaporkan dari delapan kota di Indonesia (Medan, Ujung Pandang, Palembang, Jakarta, Yogyakarta,
Surabaya, Pontianak, Manado). ${ }^{5}$ den-2 ( $\left.=57\right)$ dan den-3 ( $n=73)$ merupakan predominan. Penemuan yang sama ditemukan selama periode 1984-1985. Dari 51 isolasi virus, den-4 tidak ditemukan dan den-3 ( $\mathrm{n}=24)$ lebih predominan. ${ }^{5}$ Dari tahun 1985 sampai 1986, 36 isolat telah berhasil ditemukan dari 377 sampel serum. Serotipe yang berhasil diisolasi adalah 18 kasus den-2, 12 kasus den-3, 4 kasus den-1 dan 2 kasus den- 4 .

Dari tahun 1995-1996 dilakukan penelitian kohort prospektif di Yogyakarta, semua serotipe ditemukan pada awal penelitian. ${ }^{17}$ den-2 lebih predominan dan merupakan serotipe yang paling sering ditransmisi dari keempat serotipe selama tahun pertama penelitian. Dari anak-anak yang dirawat dengan demam, 11 dari 107 terbukti secara serologi atau virologi baru mengalami infeksi dengue. den-3 merupakan yang paling dominan dari semua kasus. Dari 6 pasien yang dirawat $(\mathrm{DBD}=3, \mathrm{DSS}=3)$ urutan infeksi ditemukan pada 5 pasien yaitu den-2 den-1 $(n=3)$, den- 2 den- 4 $(n=1)$, den-1 den-3 ( $n=1)$. Dari semua serokonversi menjadi infeksi sekunder, urutan den-2 den-1 dan den-1 den-2 merupakan yang predominan.

Pada penelitian kohort prospektif di Bandung, semua serotipe ditemukan dengan den-2 merupakan serotipe predominan. Tiga dari 4 kasus DBD disebabkan oleh virus den-3. Kasus SSD ditemukan infeksi sekunder dengan urutan den-2 den-1.

Pada penelitian kejadian luar biasa oleh Suwandono dkk di Jakarta tahun 2004, dari 28 serum dengue akut dikonfirmasi dengan RT-PCR atau kultur. ${ }^{4}$ den-3 ditemukan pada sebagian besar kasus $(n=18 ; 64,3 \%)$ diikuti oleh den-4 ( $\mathrm{n}=4 ; 14,3 \%)$, den-2 ( $\mathrm{n}=4 ; 14,3 \%)$ dan den-1 ( $\mathrm{n}=2 ; 7,1 \%)$ Isolasi den-3 menunjukkan hasil yang hampir sama dengan isolasi virus sebelumnya di Indonesia selama kejadian luar biasa pada tahun 1998.

Survei isolasi virus dengue yang dilakukan oleh Badan Penelitian dan Pengembangan Departemen Kesehatan dan laboratorium NAMRU-2 di Jakarta menunjukkan bahwa sejak tahun 1972 sampai 1992 di Indonesia keempat serotipe dengue ditemukan pada kasus DBD ringan sampai berat yang dirawat. Pada pengamatan selama tujuh belas tahun, virus dengue 
serotipe 3 dan 2 merupakan serotipe yang dominan, diikuti serotipe 1 dan 4. Pada tahun 2004, Badan Litbang Depkes melakukan isolasi virus dengan RTPCR pada periode kejadian luar biasa DBD. Serotipe virus dengue 3 masih merupakan serotipe yang paling dominan (57\%), diikuti serotipe $2(13 \%)$, serotipe 4 $(20,7 \%)$ dan serotipe $1(5,6 \%)$, sedangkan infeksi virus dengue campur dari serotipe 3 dan 1 ditemukan sejumlah 3,7\%.. ${ }^{29}$ (Gambar 2)

Pada saat terjadi kejadian luar biasa, isolasi virus dengue yang paling dominan pada bulan Maret 2004 dan Februari 2005 adalah serotipe den-2, sedangkan pada Januari 2006 dan Februari 2007 serotipe 3 paling dominan, walaupun semua serotipe virus dengue ditemukan. Jumlah kasus infeksi dengue meningkat terutama pada bulan Januari sampai Maret. Dari data tersebut maka bulan Januari merupakan periode sebaiknya dilakukan pembasmian larva dan pemberantasan sumber nyamuk yaitu sebelum periode transmisi. ${ }^{29}$

Pada bulan Maret sampai Desember 2006 dikumpulkan 141 isolasi dari pasien dengue yang dirawat di Departemen Ilmu Kesehatan anak dan Ilmu Penyakit Dalam Rumah Sakit Cipto Mangunkusumo dengan hasil serotipe terbanyak secara berurutan adalah serotipe den-2(43 kasus), den-3(25 kasus), den-1(15 kasus) dan den-4(3 kasus). Sedangkan pada tahun 2007 didapatkan 147 kasus dengue dengan serotipe den-2 dan den-3 masing-masing 20 kasus den-1 (2 kasus) dan den-1(1 kasus). ${ }^{24}$

Data serotipe dengue pada bulan Maret sampai April 2009 dari sejumlah 112 kasus anak dan dewasa di RS Cipto mangunkusumo didapatkan 19 kasus den-3, 9 kasus den-1, 9 kasus den- 2 dan 2 kasus den-4. Kasus DBD dengan syok paling banyak termasuk serotype den-3(54,54\%). ${ }^{30}$

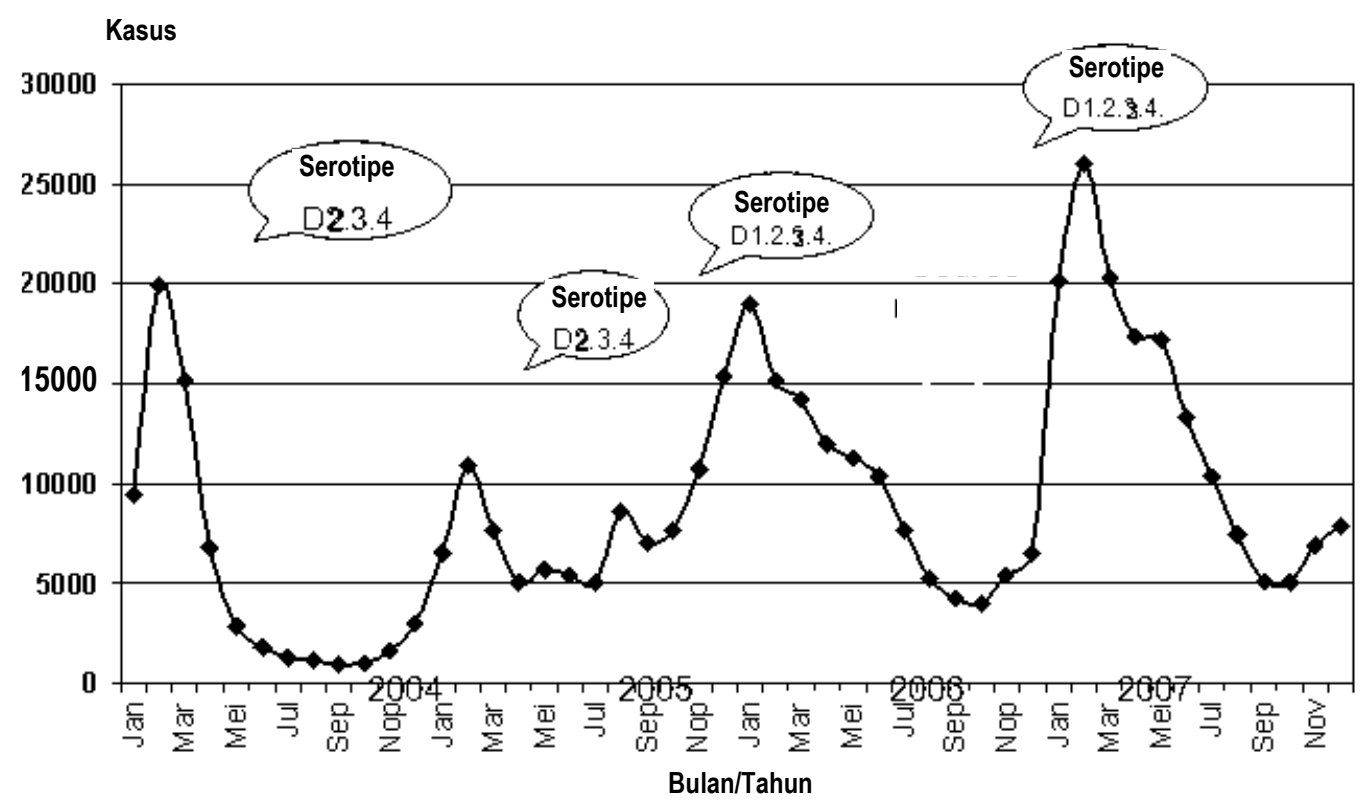

Gambar 2. Serotipe virus dengue di Indonesia dari tahun 2004-2007. ${ }^{29}$

Tabel 2. Serotipe dengue di RSCM 2006-2009. ${ }^{30}$

\begin{tabular}{lccc}
\hline Tahun & 2006 & 2007 & 2009 \\
\hline Jumlah kasus (anak dan dewasa) & 141 kasus & 97 kasus & 112 kasus \\
Serotype virus den-1 & 15 & 1 & 9 \\
Serotype virus den-2 & 43 & 20 & 9 \\
Serotype virus den-3 & 25 & 20 & 19 \\
Serotype virus den-4 & 4 & 1 & 2 \\
\hline
\end{tabular}




\section{Pembahasan}

Epidemik dari DD dan DBD merupakan masalah kesehatan masyarakat yang penting di Indonesia sejak ditemukan pada tahun 1968. Epidemiologi DBD di indonesia telah berubah dengan meningkatnya jumlah kasus dari seluruh tiga puluh tiga propinsi. Kecenderungan dari kejadian luar biasa infeksi dengue mengikuti pola siklik yang iregular dengan latar belakang endemik. Kelompok umur yang terserang dengue berubah menjadi kelompok remaja dan dewasa. ${ }^{4}$ Pada periode 1979-1984 rerata umur kasus DBD di Jakarta adalah 4-11 tahun. ${ }^{5}$ Data Departemen Kesehatan menunjukkan setelah tahun 1984 insidens kelompok umur lebih dari 15 tahun meningkat dari tahun ke tahun hingga sekarang. Hal ini juga terjadi di beberapa di Asia yang menunjukkan bahwa insidens kasus DBD mengalami pergeseran ke kelompok umur remaja. $^{3}$

Angka kematian juga cenderung menurun dari tahun ke tahun. Kewaspadaan petugas kesehatan dalam mendiagnosis pasien lebih baik mengakibatkan pengenalan infeksi dengue di fasilitas kesehatan yang tersedia lebih tepat dan dini. Protokol dan panduan lokal tata laksana dengue di Indonesia telah membantu menurunkan angka kematian, dan diharapkan akan terus menurun. Penurunan angka kematian dari 10\%$15 \%$ (40\% dibeberapa negara) pada awal tahun 1950 , saat ini menjadi kurang dari $0,5 \%$ di rumah sakit rujukan di Asia Tenggara didukung oleh pelatihan pada petugas medis yang lebih baik. ${ }^{3}$

Data derajat beratnya DBD tidak dilaporkan sehingga sulit menentukan apakah terjadi perubahan rasio dari DD, DBD dan SSD. Selain kewaspadaan, peningkatan alat dan fasilitas diagnostik juga membaik, sehingga membantu pelaporan kasus. Kejadian luar biasa lebih dikenal lebih dini, dan uji diagnostik lebih sensitif dan spesifik membantu korfirmasi diagnosis. Definisi kasus berdasarkan WHO, juga digunakan oleh Depkes, dengan kriteria diagnosis klinis dan laboratorium. Disebutkan bahwa semua kasus tersangka dan konfirmasi harus selalu dilaporkan. Karena tidak semua sarana kesehatan memiliki fasilitas laboratorium untuk konfirmasi, maka laporan kasus tidak selalu menggambarkan situasi yang sebenarnya. Pada negara dengan banyak epidemik dan transmisi endemik tinggi maka jumlah kasus sebenarnya lebih besar. ${ }^{2}$ Estimasi angka kematian DBD dari data surveillans didapatkan lebih rendah dari data penelitian sampel tunggal, yang mendukung adanya under-reporting atau salah menentukan klasifikasi kematian. World Health Organization (WHO) memperkirakan bahwa data surveilans hanya menangkap sepertiga dari total kasus DBD, sehingga insidens DBD di dunia dapat mencapai sekitar 1,5 juta kasus per tahun, bukan 0,5 juta kasus seperti yang diperkirakan oleh WHO. ${ }^{3}$

Epidemik dengue dipengaruhi beberapa faktor, yaitu faktor lingkungan, faktor biologi, dan demografi. Insidens dengue berhubungan dengan cuaca yang hangat dan kelembaban tinggi. ${ }^{31}$ Suhu yang tinggi dapat merangsang perkembangbiakan vektor ${ }^{32}$ dan perilaku nyamuk menggigit. ${ }^{33}$ Pergeseran kelompok umur, penyebaran ke pedesaan, faktor penentu sosial dan biologi dari ras dan jenis kelamin yang rentan berpengaruh terhadap pelayanan kesehatan. ${ }^{3}$ Pola peningkatan kasus infeksi dengue den-3 secara epidemiologi berhubungan dengan musim hujan karena penampungan air hujan akan menjadi tempat perkembangbiakan nyamuk. ${ }^{16,9,14,34}$

Transmisi epidemik dipengaruhi oleh vektor nyamuk, populasi yang secara imunologi rentan dan terdapat sirkulasi virus dengue. Berbagai strain virus dengue dan kemungkinan timbulnya virus dengue baru dan lebih virulen meningkatkan insidens epidemik DBD. ${ }^{35}$ Beberapa penelitian di Indonesia menunjukkan hubungan antara DBD berat dengan infeksi sekunder. ${ }^{4,17}$ Di Indonesia semua serotipe dapat teridentifikasi dan den-3 merupakan serotipe yang paling sering menyebabkan penyakit berat dan fatal. ${ }^{4,19,36,37}$

\section{Kesimpulan}

Infeksi dengue masih merupakan masalah di Indonesia, maka surveilans epidemiologi harus berlangsung baik dan terus menerus bersamaan dengan dukungan edukasi masyarakat dan program pengendalian vektor untuk mencegah transmisi. Upaya mendapatkan data epidemiologi yang lengkap harus ditunjang oleh pusat surveilans yang dilengkapi sarana dan fasilitas yang memadai dan berfungsi di semua propinsi di Indonesia dan pelaporan kasus dengue berlangsung rutin setiap bulan ke departemen kesehatan. Jumlah kasus dengue berat yang meningkat dan fatal menunjukkan bahwa masih perlu upaya pencegahan termasuk vaksinasi dengue. 


\section{Ucapan terima kasih}

Saya mengucapkan terima kasih kepada Direktur Pengendalian Penyakit Menular Langsung Departemen Kesehatan Republik Indonesia dan seluruh jajaran staf.

\section{Daftar Pustaka}

1. World Health Organization. Didapat dari: URL:http:// www.searo.who.int/. 2009. Diakses tanggal 14 Mei 2009.

2. Setiati TE, Wangenaar JF, Kruit MD, Mairuhu AT, Gorp EC, Soemantri A. Changing epidemiology of dengue haemorrhagic fever in Indonesia. Dengue Bulletin 2006;30:1-14.

3. Sapir DG, Schimmer B. Dengue fever: new paradigms for changing epidemiology. Emerging themes in Epidemiology 2005;2:1-10.

4. Suwandono A, Kosasih H, Nurhayati,Kusriastuti R, Harun S, Ma'roef C, dkk. Four dengue virus serotypes found circulating during an outbreak of dengue fever and dengue haemorrhagic fever in Jakarta, Indonesia, during 2004. Trans R Soc Trop Med Hyg 2006;100:855-62.

5. Sumarmo. Dengue haemorrhagic fever in Indonesia. Southeast Asian J Trop Med Public Health 1987;18:26974.

6. Ismangun, Wahab AS, Sutrisno R, Surjono A. Dengue haemorrhagic fever in Jogjakarta, Central Java. Paediatr Indones 1972;12:49-54.

7. Halstead SB. Is there an inapparent dengue explosion? Lancet 1999;27:1100-1.

8. Hotta S, Miyasaki K, Takehara M, Matsumoto Y, Ishihama $\mathrm{Y}$, Tokuchi $\mathrm{M}$ et al. Clinical and laboratory examinations on a case of "hemorrhagic fever" found in Surabaja, Indonesia, in 1968. Kobe J Med Sci 1970;16:203-10.

9. Nathin MA, Harun SR, Sumarmo. Dengue haemorrhagic fever and Japanese B encephalitis in Indonesia. Southeast Asian J Trop Med Public Health 1988;19:475-81.

10. Rivai A, Hamzah S, Rahman O, Thaib S.Dengue and dengue haemorrhagic fever in Bandung. Paediatr Indones 1972;12:40-8.

11. Husada T, Munir M. Dengue haemorrhagic fever in Manado, North Sulawesi. Paediatr Indones 1976;16:496508.

12. Eram S, Setyabudi Y, Sadono TI, Sutrisno DS, Gubler DJ, Sulianti SJ. Epidemic dengue hemorrhagic fever in rural Indonesia. II. Clinical studies. Am J Trop Med Hyg 1979;28:711-6.

13. Gubler DJ, Suharyono W, Lubis I, Eram S, Sulianti SJ. Epidemic dengue hemorrhagic fever in rural Indonesia. I. Virological and epidemiological studies. Am J Trop Med Hyg 1979;28:701-10.

14. Gubler DJ, Suharyono W, Lubis I, Eram S, Gunarso S. Epidemic dengue 3 in central Java, associated with low viremia in man. Am J Trop Med Hyg 1981;30:1094-9.

15. Sumarmo, Wuryadi S, Gubler DJ. Clinical observations on hospitalized patients with virologically confirmed dengue hemorrhagic fever in Jakarta, Indonesia 19751983. Paediatr Indones 1986;26:137-51.

16. Richards AL, Bagus R, Baso SM, Follows GA,Tan R, Graham RR, Sandjaja B, Corwin AL, Punjabi N. The first reported outbreak of dengue hemorrhagic fever in Irian Jaya, Indonesia. Am J Trop Med Hyg 1997;57:4955.

17. Graham RR, Juffrie M, Tan R, Hayes CG,Laksono I, Ma'roef C, Erlin, dkk. A prospective seroepidemiologic study on dengue in children four to nine years of age in Yogyakarta, Indonesia I. studies in 1995-1996. Am J Trop Med Hyg 1999;61:412-9.

18. Suroso T, Holani A, Imran I. Dengue haemorrhagic fever outbreaks in Indonesia 1997-1998. Dengue Bulletin 1998;22:45-8.

19. Corwin AL, Larasati RP, Bangs MJ, Wuryadi S, Arjoso S, Sukri N, Listyaningsih E, dkk. Epidemic dengue transmission in Southern Sumatra, Indonesia. Trans R Soc Trop Med Hyg 2001;95:257-65.

20. Porter KR, Beckett CG, Kosasih H, Tan RI, Alisjahbana B, Rudiman PI, dkk. Epidemiology of dengue and dengue hemorrhagic fever in a cohort of adults living in Bandung, West Java, Indonesia. Am J Trop Med Hyg 2005;72:60-6.

21. Sukri NC, Laras K, Wandra T, Didi S, Larasati RP, Rachdyatmaka JR, Osok S, dkk. Transmission of epidemic dengue hemorrhagic fever in easternmost Indonesia. Am J Trop Med Hyg 2003;68:529-35.

22. Beckett CG, Kosasih H, Faisal I, Nurhayati, Tan R, Widjaja S, Listiyaningsih E, dkk. Early detection of dengue infections using cluster sampling around index cases. Am J Trop Med Hyg 2005;72:777-82.

23. Ahmad K. Dengue death toll rises in Indonesia. Lancet 2004;20:956.

24. Sudhiro TM, Dewi BE, Chandra R, Cucunawangsih, Suhendro, Pohan H, Karyanti MR. Sequence analysis of the envelope genes of dengue viruses type 1, 2, and 3 and NS-1 gene of dengue virus type 3 isolated in Jakarta. 
PERMI PIT 2007.

25. Data Divisi Infeksi dan Pediatri Tropik, Departemen Ilmu Kesehatan Anak RSCM-FKUI 2009.

26. Van Peenen PF, Rosen L, Sulianti SJ, Irsiana R.Letter: Follow up on dengue types in Jakarta, Indonesia. Trans R Soc Trop Med Hyg 1974;68:342-3.

27. Van Peenen PF, Sunoto, Sumarmo, Sulianti Saroso J, Sinto S, Joseph PL, See R. Dengue with haemorrhage and shock in Jakarta, Indonesia. Southeast Asian J Trop Med Public Health 1978;9:25-32.

28. Trastotenojo MS, Anggoro S, Soemantri AG, Thaib S. A report on dengue hemorrhagic fever patients with viral isolation. Paediatr Indones 1975;15:169-80.

29. Data Direktur Pengendalian Penyakit Menular Langsung Departemen Kesehatan Republik Indonesia 2009. (tidak dipublikasi)

30. Sudhiro TM. Serotipe dan sequencing dengue of dengue cases in Cipto Mangunkusumo hospital 2009.

31. Rigau-Perez JG, Clark GG, Gubler DJ, Reiter P,Sanders EJ, Vorndam AV. Dengue and dengue haemorrhagic fever. Lancet 1998;352:971-7.

32. Watts DM, Burke DS, Harrison BA, Whitmire RE, Nisalak A. Effect of temperature on the vector efficiency of Aedes aegypti for dengue 2 virus. Am J Trop Med Hyg 1987;36:143-52.

33. Yasuno M, Tonn RJ. A study of biting habits of Aedes aegypti in Bangkok, Thailand. Bull World Health Organ 1970;43:319-25.

34. Suharyono W, Gubler DJ, Lubis I, Tan R, Abidin M, Sie A, Saroso JS. Dengue virus isolation in Indonesia, 1975-1978. Asian J Infect Dis 1979;3:27-32.

35. Guzman MG, Kouri G. Dengue: an update.Lancet Infect Dis 2002;2:33-42.

36. Streatfield R, Bielby G, Sinclair D. A primary dengue 2 epidemic with spontaneous haemorrhagic manifestations. Lancet 1993;28:560-1.

37. Fujita N, Hotta S, Konishi E, Esaki H, Sumarmo, Sujudi. Dengue hemorrhagic fever in Jakarta, Indonesia in 1988: isolation of dengue virus from patient whole blood using cell cultures. Am J Trop Med Hyg 1997;56:318 -21. 